\title{
Türkiye'nin farklı bölgelerinden toplanan süt örneklerinde bazı metal düzeyleri
}

\author{
Erdim Ozan Çakır ${ }^{* *}($ (D), Ender Yarsan² (0) \\ ${ }^{1}$ Pendik Veteriner Kontrol Enstitüsü, Ilaç Kalite Kontrol Laboratuvarı, İstanbul, Türkiye \\ ${ }^{2}$ Ankara Üniversitesi Veteriner Fakültesi, Ankara, Türkiye
}

Geliş Tarihi / Received: 22.02.2021, Kabul Tarihi / Accepted: 03.05.2021

\begin{abstract}
Özet: Süt, yaşamın her evresinde önemli bir besin kaynağıdır. Sütün bileşimi, kalıtımsal, fizyolojik ve çevresel faktörler ile yetiştirme koşullarına bağlı olarak büyük ölçüde değişir. Günümüzde endüstrideki hızlı gelişmeye bağlı olarak ortaya çıkan çevre kirliliğinin olumsuz etkilerinden birisi de insan ve hayvanların ağır metallere maruz kalmasıdır. Sütün kontaminasyonu, insan ve hayvan sağlığı için tehdit oluşturmaktadır. Bu olası etkileri değerlendirmek amacıyla Marmara, Karadeniz, Iç Anadolu, Doğu Anadolu, Akdeniz ve Ege bölgelerinden, 2007 yılında üçer aylık dört dönemde temin edilen numunelerde, sütün yapısında bulunan demir (Fe), bakır (Cu), çinko (Zn) yanında sütte bulunması muhtemel kurşun $(\mathrm{Pb})$ ve kadmiyum $(\mathrm{Cd})$ düzeyleri yönünden analizler yapıldı. Pb ve Cd analizleri Grafit Fırınlı Atomik Absorbsiyon Spektrometre (GF-AAS), Fe, Cu ve Zn analizleri ise Alevli Atomik Absorbsiyon Spektrometre (A-AAS) ile gerçekleştirildi. Pb yönünden örneklerin 10'unun $(\% 8,3)$ maksimum kalıntı limitlerini aştığı, ancak genel ortalamanın bu değerin altında olduğu görüldü. $\mathrm{Cd}, \mathrm{Cu}$, Fe, ve Zn yönünden normal sınırlar içerisinde olduğu ve insan sağlığı yönünden risk oluşturacak düzeyde olmadığı tespit edildi.
\end{abstract}

Anahtar kelimeler: Ağır metal, Atomik absorpsiyon spektrometre, süt, Türkiye

\section{Some metal levels in milk samples which were collected from different regions of Turkey}

\begin{abstract}
Milk is an important food source in every stage of life. The composition of milk varies greatly depending on the animal-source, hereditary, physiological and environmental factors and the husbandry conditions. Today, one of the negative effects of environmental pollution, which occurs due to the rapid development in industry, is the exposure of humans and animals to heavy metals. Milk contamination poses a threat to human and animal health. In order to assess these potential effects iron (Fe), copper (Cu) and zinc ( $\mathrm{Zn}$ ), which are generally found in the composition of the milk as well as possibly found lead $(\mathrm{Pb})$ and cadmium $(\mathrm{Cd})$ levels were analyzed in samples obtained from Marmara, Black Sea, Central Anatolia, Eastern Anatolia, Mediterranean and Aegean regions for four quarterly periods in 2007. Pb and Cd analyzes were performed with Graphite Furnace Atomic Absorption Spectrometer (GF-AAS) and Fe, $\mathrm{Cu}$ and $\mathrm{Zn}$ analyzes were performed with Flamed Atomic Absorption Spectrometer (F-AAS). It was seen that $10(8.3 \%)$ of the samples exceeded the maximum residue limits in terms of $\mathrm{Pb}$, but the average was below this value. $\mathrm{Cd}, \mathrm{Cu}, \mathrm{Fe}$, and $\mathrm{Zn}$ were found to be within normal limits and not to pose a risk for human health.
\end{abstract}

Keywords: Atomic absorption spectrometer, heavy metal, milk, Turkey

\section{Giriş}

Süt, geniş anlamda bütün memeli hayvanların yavrulamalarından sonra meme bezlerinde oluşturdukları biyolojik salgı olarak tanımlanır (Tekinşen 2000). Çiğ süt ise, bir veya daha fazla inek, keçi, koyun veya mandanın sağılmasıyla elde edilen, $40^{\circ} \mathrm{C}$ 'nin üzerinde ısıtılmamış veya eşdeğer etkiye sahip herhangi bir işlem görmemiş kolostrum dişındaki meme bezi salgısıdır (Anon 2011a).

Sütün bileşimi ve elementer içeriği, önemli ölçüde farklılık gösterir. Değişimler başlıca, ineğin fizyolojisi (laktasyon dönemi, gebelik, yaş, meme sağlığı) ile kalıtım ve çevre faktörlerine, bir ölçüde de sağım sırası, arası ve sonrası işlemlere bağlıdır (Tekinşen 2000).

Süt ve süt ürünleri beslenme açısından, oldukça önemli bir besin grubu olup, yaşamlarının her evresinde insanlar için gereklidir. Bu durumun temel sebebi; süt ve süt ürünlerinin çeşitli besin öğeleri açısından iyi bir kaynak olmalarıdır.

Günümüzde endüstrideki hızlı gelişmeye bağlı olarak ortaya çıkan çevre kirliliğinin olumsuz etkilerinden birisi de insan ve hayvanların solunum ve beslenme yoluyla ağır metallere maruz kalmasıdır. Her çevre sorununun kökeninde hava, su ve topraktan en az birinin doğal bileşiminin bozularak 
kirlenmesi yatmaktadır. Özgül ağırlıkları $5 \mathrm{~g}$ ve bu değerin üzerinde olan metaller, ağır metal olarak nitelenmekte (Ag, As, Cd, Cu, $\mathrm{Fe}, \mathrm{Hg}, \mathrm{Ni}, \mathrm{Pb}, \mathrm{Zn}$ gibi) ve bunların çok yönlü zararlara neden oldukları bilinmektedir (Algan 2002; Özrenk 2002).

Canlı organizmada çeşitli biyokimyasal işlevlere sahip olan ve gıdalar aracılığıyla alınan demir (Fe), çinko (Zn) ve bakır (Cu) gibi elementler insan vücudu için gereklidir. Bununla birlikte tavsiye edilen miktar üzerindeki seviyeleri toksik hale gelebilir. Organizma için gerekli olmayan Kadmiyum (Cd) ve kurşun $(\mathrm{Pb})$ gibi ağır metallerin ise bilinen biyolojik bir rolü yoktur, çok düşük konsantrasyonlarda toksik etkilere neden olabilir. Bu nedenle, gıdalar aracılığıyla ağır metallere maruziyet, insan sağlığına tehdit oluşturmaktadır. Dekompozisyon için uygun olmamaları, parçalanmamaları, yaşam boyu maruziyet ve gıda zinciri aracılığıyla yüksek seviyede birikmeleri, ağır metalleri diğer bulaşanlardan ayırır (Boudebbouz 2021).

Vücuda alınan kurşun, öncelikle hemoglobin sentezini ALA-D (delta- aminolevülinik asit dehidraz) ve hem sentetaz enzimlerini inhibe ederek iki aşamada bloke eder. Anemiye sebep olur. Kurşun doğrudan alyuvarlarda parçalanmaya yol açar (Kaya ve Akar, 1998).

Kurşunun en önemli toksik zararlarından birisi de merkezi sinir sistemi üzerine olan etkisidir. Etkilenme nedeniyle özellikle çocuklarda zihinsel hasarlar, öğrenme yeteneğinde azalma ve davranış bozuklukları görülebilir (Özrenk 2002).

FAO/ WHO uzmanlar komitesi (JECFA) geçici tolere edilebilir haftalık alım miktarını $25 \mathrm{mg} / \mathrm{L}$ vücut ağırlığı olarak belirlemiştir. Kodeks Alimentarius Komisyonu (CAC) tarafından tavsiye edilen haftalık sınır ise, 0,05 mg/L vücut ağırlığıdır. Değişik analitik veriler dikkate alındığında sütteki normal kurşun miktarlarının 0.01-0.05 mg/L arasında değiştiği ifade edilebilir. Günde 1 litre ortalama seviyede kurşun içeren süt tüketildiğinde (ve / veya denk miktarda süt ürünleri), tolere edilebilir kurşun alınımında sütün etkisi \%1'den az olmaktadır. 1881/2006 EC sayıIı Avrupa Birliği Komisyon Tüzüğü çiğ süt için 0.02 mg/L düzeyinde sınırlama getirmiştir (Anon 2006).

Kadmiyum, endüstriyel kullanımı yaygın kanserojen, toksik bir elementtir. Uzun yarı ömrü (15-30 yıl) ve insan sağlığı üzerinde teratojenik, kanserojenik, hepatotoksik, nefrotoksik, iskelet ve üreme sistemlerine çok yönlü zararlı etkileri nedeniyle en toksik endüstriyel ve çevresel ağır metallerden biri kabul edilmektedir (Boudebbouz 2021).
JECFA insanların her kg ağırlığı başına haftalık $0.007 \mathrm{mg} / \mathrm{L}$ kadmiyum almasına tolerans tanınmıştır. Öte yandan bazı özel yiyeceklerin alımı ile (örneğin böbrek ve keten tohumu) önerilen değerlerden daha fazla kadmiyum alınabildiği yapılan bir takım çalışmalarda gösterilmiştir. İnek sütünün kadmiyum içeriği 0,0002 mg/L ile 0,0008 mg/L (ortalama 0.0005 $\mathrm{mg} / \mathrm{L}$ ) arasında bulunmaktadır. Bazı ülkeler süt için Tablo 1'de belirtilen kendi kabul edilebilir değerlerini tespit etmiş̧ir (Kınık ve ark. 2001).

Tablo 1. Bazı ülkelerdeki sütte kabul edilebilir kadmiyum düzeyleri

\begin{tabular}{lc}
\hline Ülke & Miktar $(\mathbf{m g} / \mathbf{k g})$ \\
\hline Almanya & 0.005 \\
Danimarka & 0.01 \\
Hollanda & 0.005 \\
Avustralya & 0.05 \\
Slovakya & 0.01 \\
\hline
\end{tabular}

Demir, Bakır ve Çinko toksikolojik etkilerinden ziyade, lipid oksidasyonu nedeniyle süt ve süt ürünlerinin tat ve aromasını olumsuz yönde etkilemektedir.

Bu çalışma, Türkiye'nin farklı bölgelerinden temin edilen çiğ inek sütlerinde $\mathrm{Fe}, \mathrm{Cu}, \mathrm{Zn}, \mathrm{Pb}$ ve $\mathrm{Cd}$ düzeylerinin belirlenmesi amacıyla gerçekleştirilmiştir. Bu kapsamda, Marmara, Karadeniz, İç Anadolu, Doğu Anadolu, Akdeniz ve Ege bölgelerinden örnekler alınmış, metal içerikleri uygun analitik metotlarla tespit edilerek özellikle mevsimsel değişiklikler literatür bilgileri ile karşılaştırılarak değerlendirilmiştir.

\section{Gereç ve Yöntem}

Bu çalışmada, Türkiye'nin 6 farklı bölgesinden (Marmara, Karadeniz, İç Anadolu, Doğu Anadolu, Akdeniz ve Ege) 3'er aylık periyotlarla, 4 dönemde temin edilen çiğ inek sütlerinde kurşun, kadmiyum, demir bakır ve çinko düzeyleri yönünden analizler yapıldı. Bu kapsamda her bölgeden 20 adet olacak şekilde, 120 örnek (Tablo 2) alındı. Örnekler 100 ml miktarda propilen kaplara konuldu. Örnek toplama işlemi, Tarım ve Orman Bakanlığı'nın "Canlı Hayvanlar ve Hayvansal Ürünlerde Belirli Maddeler ile Bunların Kalıntılarının İzlenmesi için Alınacak Önlemlere Dair Yönetmelik" (Anon, 2011b) ilkeleri doğrultusunda yapıldı. Bu amaçla süt örnekleri süt toplama tanklarından doğrudan alındı ve plastik tüpler içerisinde laboratuvara getirildi. Alınan örnekler analiz edilinceye kadar derin dondurucuda $-18^{\circ} \mathrm{C}^{\prime}$ de muhafaza edildi. 
Tablo 2. Süt numunelerinin toplandığı dönemler

\begin{tabular}{llc}
\hline & Dönem & Numune Sayısı \\
\hline 1 & Aralık 2006 - Şubat 2007 & 30 \\
2 & Mart 2007 - Mayıs 2007 & 30 \\
3 & Haziran 2007 - Ağustos 2007 & 30 \\
4 & Eylül 2007 - Kasım 2007 & 30 \\
\hline
\end{tabular}

\section{Yöntem}

\section{Süt Örneklerin Hazırlanması}

Süt örneklerinde metallerin analizleri AOAC metot 999.10 (mikrodalga yakma metodu ile hazırlanan gıdalarda $\mathrm{Pb}, \mathrm{Cd}$, Fe, Cu ve $\mathrm{Zn}$ düzeyinin AAS ile tespiti) ile gerçekleştirildi (AOAC 2000).

Analiz aşamasında, oda sıcaklığına getirilen dondurulmuş süt örnekleri homojenleştirildi ve teflon kaplara 2'şer ml miktarda alındı. Örneklerin üzerine $5 \mathrm{ml} \mathrm{HNO}_{3}$ (\%65) ve $2 \mathrm{ml} \mathrm{H} \mathrm{O}_{2}$ (\%30) (Merck, ABD) eklenerek kapakları kapatıldı. Berghof MWS-2 (Almanya) model mikrodalga fırına konulan örnekler Tablo 3'de belirtilen parametrelere göre işleme tabi tutuldu.

Tablo 3. Mikrodalga firın parametreleri

\begin{tabular}{cccc}
\hline Aşama & Sıcaklık $\left({ }^{\circ} \mathbf{C}\right)$ & Güç (watts) & Süre (dakika) \\
\hline 1 & 160 & 0,8 & 15 \\
2 & 210 & 0,8 & 15 \\
3 & 100 & 0,8 & 15 \\
\hline
\end{tabular}

İşlemin sonunda teflon kaplar, kapakları açılmadan 15 dakika süre ile çeker ocak altında soğumaya bırakıldı ve sürenin sonunda açılarak kapak ve teflon kap iç duvarı aşağı doğru deiyonize su ile yıkandı. İçerik süzgeç kâğıdından süzülerek 15 ml'lik propilen tüplere alındı ve üzeri 15 ml'ye kadar bidistile su ile tamamlandı. Bu şekilde örnekler AAS'de analiz edilebilecek forma getirildi, analiz yapılıncaya kadar $+4^{\circ} \mathrm{C}$ 'de buzdolabında bekletildi.

\section{Atomik Absorpsiyon Spektroskopisi}

Işık kaynağı olarak her metalin kendine özgü dalga boyunda ışıma yapan oyuk katot lambaları, Cd için ise elektrotsuz boşalım lambası kullanıldı. Alevle atomlaştırma için çok sayıda metalin analiz edilmesine uygun bir ortam ve yeterli sıcaklığı (2125$2400^{\circ} \mathrm{C}$ ) sağlayan hava/asetilen karışımı, grafit $\mathrm{fı}-$ rınında ise inert gaz olarak argon kullanıldı. $\mathrm{Pb}$ ve $\mathrm{Cd}$ analizleri Grafit Fırınlı AAS (GF-AAS) ve Zeeman zemin düzeltici sistem ile, $\mathrm{Fe}$, $\mathrm{Cu}$ ve $\mathrm{Zn}$ analizleri ise Alevli AAS (A-AAS) cihazı ile deuterium zemin düzeltici sistem kullanılarak yapıldı. Çalışılan metaller için kullanıcı parametreleri Tablo 4-7'de gösterildi.
Tablo 4. Alevli AAS için analiz parametreleri

\begin{tabular}{cccccc}
\hline Element & $\begin{array}{c}\text { Dalga } \\
\text { boyu } \\
\text { (nm) }\end{array}$ & $\begin{array}{c}\text { Slit } \\
\text { açılığı } \\
\text { (nm) }\end{array}$ & $\begin{array}{c}\text { Lamba } \\
\text { akımı } \\
\mathbf{( m A )}\end{array}$ & $\begin{array}{c}\text { Asetilen } \\
\text { (L/dk) }\end{array}$ & $\begin{array}{c}\text { Hava } \\
\text { (L/dk) }\end{array}$ \\
\hline $\mathrm{Fe}$ & 248.3 & $0.2 \mathrm{H}$ & 30 & 2.0 & 17 \\
$\mathrm{Cu}$ & 324.8 & $0.7 \mathrm{H}$ & 30 & 44257 & 18 \\
$\mathrm{Zn}$ & 213.9 & $0.7 \mathrm{H}$ & 25 & 2.0 & 17 \\
\hline
\end{tabular}

Tablo 5. Grafit Fırınlı AAS için analiz parametreleri

\begin{tabular}{lcc}
\hline Parametreler & $\mathbf{P b}$ & $\mathbf{C d}$ \\
\hline Lamba tipi & $\mathrm{C}-\mathrm{HCL}$ & $\mathrm{EDL}$ \\
Dalga boyu $(\mathrm{nm})$ & 283.3 & 228.8 \\
Slit açıklı̆ı $(\mathrm{nm})$ & $0.7 \mathrm{~L}$ & $0.7 \mathrm{~L}$ \\
Lamba akımı $(\mathrm{mA})$ & 30 & 230 \\
Örnek hacmi $(\mu \mathrm{l})$ & 20 & 20 \\
Modifier $(\mu \mathrm{l})$ & 5 & 5 \\
\hline
\end{tabular}

Tablo 6. Kurşun elementinin sıcaklık programı

\begin{tabular}{lcccc}
\hline Basamak & $\begin{array}{c}\text { Sıcaklık } \\
\left({ }^{\circ} \mathbf{C}\right)\end{array}$ & $\begin{array}{c}\text { Yükselme } \\
\text { Süresi }(\mathbf{s})\end{array}$ & $\begin{array}{c}\text { Tutma } \\
\text { Süresi }(\mathbf{s})\end{array}$ & $\begin{array}{c}\text { Argon Akışı } \\
(\mathbf{m l} / \text { dak.) }\end{array}$ \\
\hline Kurutma1 & 110 & 5 & 15 & 250 \\
Kurutma2 & 500 & 10 & 25 & 250 \\
Külleme & 900 & 15 & 35 & 250 \\
Atomizasyon & 1800 & 0 & 1 & 0 \\
Temizleme & 2600 & 1 & 2 & 250 \\
\hline
\end{tabular}

Tablo 7. Kadmiyum elementinin sıcaklık programı

\begin{tabular}{lcccc}
\hline Basamak & $\begin{array}{c}\text { Sıcaklık } \\
\left({ }^{\circ} \mathbf{C}\right)\end{array}$ & $\begin{array}{c}\text { Yükselme } \\
\text { Süresi (s) }\end{array}$ & $\begin{array}{c}\text { Tutma } \\
\text { Süresi (s) }\end{array}$ & $\begin{array}{c}\text { Argon Akışı } \\
(\mathbf{m l} / \text { dak.) }\end{array}$ \\
\hline Kurutma1 & 110 & 1 & 30 & 250 \\
Kurutma2 & 130 & 15 & 30 & 250 \\
Külleme & 500 & 10 & 20 & 250 \\
Atomizasyon & 1500 & 0 & 5 & 0 \\
Temizleme & 2450 & 1 & 3 & 250 \\
\hline
\end{tabular}

Atomik Absorpsiyon Spektrometre bağıl bir metot olup bilinmeyenin yoğunluğu standart çözeltilerle karşılaştırılarak bulunur. Bunun için cihaz, analiz edilecek her element için 1000 mg/L'lik stok çözeltisinden hazırlanan farklı yoğunluklardaki standartlar (High Purity, ABD) ile kalibre edildi.

$\mathrm{Bu}$ çalışmada incelenen $\mathrm{Pb}, \mathrm{Cd}, \mathrm{Fe}, \mathrm{Cu}$ ve $\mathrm{Zn}$ miktarları Tarım ve Orman Bakanlığı Veteriner Kontrol Merkez Araştırma Enstitüsü Biyokimya Laboratuvarı'ndaki Perkin Elmer AAnalys 800 AAS (ABD) ile ölçülmüştür. Okumanın yapıldığı AAS cihazı 0.001 $\mu \mathrm{g} / \mathrm{L}$ hassasiyetle çalışmaktadır. Okuma değerleri bu değerden daha düşük olan veriler, sıfır olarak değerlendirildi ve istatistik analizlerde de eksik gözlem olarak kabul edildi. Fe, Cu, ve Zn düzeyleri Alevli AAS 
cihazı ile doğrudan ölçüldü. Grafit Fırınlı AAS cihazı ile çalışmaya başlamadan önce örnek hacimleri, istenilen sıcaklığa ulaşma süresi ve bu sıcaklıkta kalma süresi, kurutma, külleştirme, atomizasyon ve grafit tüpün temizlenmesi aşamalarındaki sıcaklıklar analiz öncesinde en üst düzeyde verim sağlayacak şekilde ayarlandı. Kurşun için $\mathrm{NH}_{4} \mathrm{H}_{2} \mathrm{PO}_{4}$ ve kadmiyum için $\mathrm{Mg}\left(\mathrm{NO}_{3}\right)_{2}$ matriks değiştirici (modifier) olarak kullanıldı. Her bir numuneden $20 \mu$ olacak şekilde ve üzerine $\mathrm{Pb}$ ve $\mathrm{Cd}$ için $5 \mu \mathrm{l}$ matriks değiştirici eklenerek, 3 tekrar analiz gerçekleştirildi ve sonuçların ortalaması alındı. Elde edilen veriler, bilgisayar programı kullanılarak takip edildi. Çalışma sonunda elde edilen verilerin istatistik değerlendirmesi SPSS (16.0.0) istatistik paket programı ile yapıldı. Bu kapsamda, aritmetik ortalama, standart sapma, en alt ve en üst değerler belirlendi. Genel olarak bölgeler ve dönemler arasındaki farklılıkların tespiti ise tek yönlü varyans analizi ve Duncan's testi ile gerçekleştirildi.

\section{Bulgular}

Analizlere başlamadan önce, AAS cihazı, her element için belirlenen konsantrasyonlarda standartlar kullanılarak kalibre edildi. Yöntemin duyarııı̆ını gösterecek geri kazanım çalışmaları sonucunda elde edilen değerler \%92,2 - 110,2 aralığında bulundu. Birinci, ikinci, üçüncü ve dördüncü dönemlere ait $\mathrm{Pb}$, $\mathrm{Cd}, \mathrm{Fe}, \mathrm{Cu}$ ve $\mathrm{Zn}$ değerleri Tablo 8-11'de verilmiştir.
Tüm dönemlere ait numuneler bir bütün olarak değerlendirildiğinde $\mathrm{Pb}$ ortalama değeri 8,38 $\pm 9,01$ $\mu \mathrm{g} / \mathrm{L}$ olarak tespit edildi. Dönemlere göre en yüksek ortalama $\mathrm{Pb}$ değeri 11,57 $\pm 13,69 \mu \mathrm{g} / \mathrm{L}$ ile birinci dönem; en düşük Pb ortalama değeri ise 2,76 $\pm 2,16$ $\mu \mathrm{g} / \mathrm{L}$ ile ikinci dönemde tespit edildi. Dönem ve bölgelere göre elde edilen değerler.

Kadmiyum ortalama değeri $0,09 \pm 0,09 \mu \mathrm{g} / \mathrm{L}$ tespit edildi. Dönemlere göre en yüksek ortalama $\mathrm{Cd}$ değeri $0,12 \pm 0,12 \mu \mathrm{g} / \mathrm{L}$ ile birinci dönem; en düşük $\mathrm{Cd}$ ortalama değeri ise $0,06 \pm 0,04 \mu \mathrm{g} / \mathrm{L}$ ile ikinci dönemde tespit edildi.

Bakır ortalama değeri $0,33 \pm 0,23 \mathrm{mg} / \mathrm{L}$ tespit edildi. Dönemlere göre en yüksek ortalama Cu değeri 0,54 $0,16 \mathrm{mg} / \mathrm{L}$ ile ikinci dönem; en düşük $\mathrm{Cu}$ ortalama değeri ise $0,23 \pm 0,19 \mathrm{mg} / \mathrm{L}$ ile üçüncü dönemde tespit edildi.

Demir ortalama değeri $0,23 \pm 0,10 \mathrm{mg} / \mathrm{L}$ tespit edildi. Dönemlere göre en yüksek ortalama Fe de-

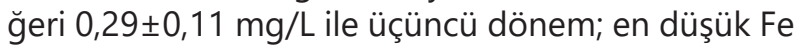
ortalama değeri ise $0,21 \pm 0,08 \mathrm{mg} / \mathrm{L}$ ile dördüncü dönemde tespit edildi.

Çinko ortalama değeri $3,67 \pm 0,86 \mathrm{mg} / \mathrm{L}$ tespit edildi. Dönemlere göre en yüksek ortalama Zn değeri 4,02 $\pm 0,88 \mathrm{mg} / \mathrm{L}$ ile birinci dönem; en düşük $\mathrm{Zn}$ ortalama değeri ise $3,18 \pm 0,68 \mathrm{mg} / \mathrm{L}$ ile üçüncü dönemde tespit edildi.

$\mathrm{Pb}, \mathrm{Cd}, \mathrm{Fe}, \mathrm{Cu}$ ve $\mathrm{Zn}$ ortalama değerleri Şekil 1-5'de verildi.

Tablo 8. Birinci dönem (kış) numunelerde tespit edilen metallerin bölgelere göre düzeyleri

\begin{tabular}{|c|c|c|c|c|c|}
\hline $\begin{array}{c}\text { Metal } \\
\text { / } \\
\text { Bölge } \\
\end{array}$ & $\begin{array}{c}\mathrm{Pb} \text { (ppb) } \\
\text { Ort. } \pm \text { SD } \\
\text { (En alt-En üst) }\end{array}$ & $\begin{array}{c}C d(p p b) \\
\text { Ort. } \pm \text { SD } \\
\text { (En alt-En üst) }\end{array}$ & $\begin{array}{c}\text { Fe (ppm) } \\
\text { Ort. } \pm \text { SD } \\
\text { (En alt-En üst) }\end{array}$ & $\begin{array}{c}\text { Cu (ppm) } \\
\text { Ort. } \pm \text { SD } \\
\text { (En alt-En üst) }\end{array}$ & $\begin{array}{c}\text { Zn (ppm) } \\
\text { Ort. } \pm \text { SD } \\
\text { (En alt-En üst) }\end{array}$ \\
\hline \multirow{2}{*}{ İç Anadolu } & $9,15 \pm 7,22^{\mathrm{a}}$ & \multirow{2}{*}{$<L O D$} & $0,25 \pm 0,04^{a}$ & $0,05 \pm 0,07^{a}$ & $3,98 \pm 0,42$ \\
\hline & $(3,00-21,00)$ & & $(0,22-0,33)$ & $(0,01-0,19)$ & $(3,60-4,52)$ \\
\hline \multirow{2}{*}{ Marmara } & $13,05 \pm 8,78^{a b}$ & $0,08 \pm 0,02$ & $0,34 \pm 0,02^{d}$ & $0,19 \pm 0,17^{a}$ & $3,52 \pm 0,73$ \\
\hline & $(4,50-27,00)$ & $(0,07-0,10)(n: 3)$ & $(0,32-0,37)$ & $(0,02-0,44)$ & $(2,78-4,67)$ \\
\hline \multirow{2}{*}{ Ege } & $27,30 \pm 22,30^{b}$ & \multirow{2}{*}{$<L O D$} & $0,24 \pm 0,02^{\mathrm{a}}$ & $0,11 \pm 0,12^{\mathrm{ab}}$ & $4,05 \pm 0,26$ \\
\hline & $(2,25-59,25)$ & & $(0,22-0,27)$ & $(0,04-0,32)$ & $(3,78-4,41)$ \\
\hline \multirow{2}{*}{ Akdeniz } & $13,12 \pm 13,28^{a}$ & $0,07 \pm 0,02$ & $0,25 \pm 0,04^{a}$ & $0,28 \pm 0,14^{b}$ & $4,68 \pm 1,13$ \\
\hline & $(3,75-32,25)(n: 4)$ & $(0,06-0,10)(n: 2)$ & $(0,19-0,30)$ & $(0,14-0,51)$ & $(3,37-5,72)$ \\
\hline \multirow{2}{*}{ Karadeniz } & $3,75 \pm 2,05^{a}$ & \multirow{2}{*}{$<L O D$} & $0,18 \pm 0,04^{b}$ & $0,47 \pm 0,18^{c}$ & $3,66 \pm 0,80$ \\
\hline & $(0,75-6,00)$ & & $(0,11-0,23)$ & $(0,34-0,66)$ & $(2,99-4,98)$ \\
\hline \multirow{2}{*}{ Doğu Anadolu } & $1,31 \pm 0,37^{a}$ & 0,45 & $0,09 \pm 0,04^{c}$ & $0,70 \pm 0,04^{d}$ & $4,29 \pm 1,35$ \\
\hline & $(0,75-1,50)(n: 4)$ & $(0,45-0,45)(n: 1)$ & $(0,04-0,16)$ & $(0,66-0,76)$ & $(2,23-5,70)$ \\
\hline
\end{tabular}

$a, b, c$, d. Aynı sütunda farklı harflerle gösterilen gruplar arasındaki fark istatistiki olarak önemlidir $(p<0,05)$. 
Tablo 9. İkinci dönem (ilkbahar) numunelerde tespit edilen metallerin bölgelere göre düzeyleri

\begin{tabular}{|c|c|c|c|c|c|}
\hline $\begin{array}{c}\text { Metal } \\
\text { / } \\
\text { Bölge } \\
\end{array}$ & $\begin{array}{c}\text { Pb (ppb) } \\
\text { Ort. } \pm \text { SD } \\
\text { (En alt-En üst) }\end{array}$ & $\begin{array}{c}\text { Cd (ppb) } \\
\text { Ort. } \pm \text { SD } \\
\text { (En alt-En üst) }\end{array}$ & $\begin{array}{c}\text { Fe (ppm) } \\
\text { Ort. } \pm \text { SD } \\
\text { (En alt-En üst) }\end{array}$ & $\begin{array}{c}\text { Cu (ppm) } \\
\text { Ort. } \pm \text { SD } \\
\text { (En alt-En üst) }\end{array}$ & $\begin{array}{c}\text { Zn (ppm) } \\
\text { Ort. } \pm \text { SD } \\
\text { (En alt-En üst) }\end{array}$ \\
\hline \multirow{2}{*}{ İç Anadolu } & $3,30 \pm 2,58$ & \multirow{2}{*}{$0,07 \pm 0,08$} & $0,17 \pm 0,04^{\mathrm{ab}}$ & $0,69 \pm 0,09^{a}$ & $3,95 \pm 0,74^{\mathrm{ab}}$ \\
\hline & $(0,75-7,50)$ & & $(0,13-0,23)$ & $(0,57-0,77)$ & $(3,43-5,24)$ \\
\hline \multirow{2}{*}{ Marmara } & $2,50 \pm 0,40$ & $0,06 \pm 0,04$ & $0,17 \pm 0,025^{a b}$ & $0,70 \pm 0,12^{\mathrm{a}}$ & $3,31 \pm 0,52^{\mathrm{a}}$ \\
\hline & $(2,25-3,00)(n: 3)$ & $(0,008-0,10)(n: 4)$ & $(0,15-0,21)$ & $(0,62-0,915)$ & $(2,55-3,93)$ \\
\hline \multirow{2}{*}{ Ege } & $2,25 \pm 2,03$ & \multirow{2}{*}{$0,07 \pm 0,04$} & $0,09 \pm 0,05^{a}$ & $0,58 \pm 0,02^{b}$ & $3,26 \pm 0,67^{a}$ \\
\hline & $(0,75-5,25)(n: 4)$ & & $(0,03-0,16)$ & $(0,56-0,62)$ & $(2,59-4,00)$ \\
\hline \multirow{2}{*}{ Akdeniz } & $1,0 \pm 0,43$ & \multirow{2}{*}{$<L O D$} & $0,19 \pm 0,11^{b}$ & $0,58 \pm 0,52^{b}$ & $3,99 \pm 0,47^{\mathrm{ab}}$ \\
\hline & $(0.75-3,75)(n: 3)$ & & $(0,02-0,30)$ & $(0,50-0,63)$ & $(3,66-4,76)$ \\
\hline \multirow{2}{*}{ Karadeniz } & 3 & \multirow{2}{*}{$<L O D$} & $0,28 \pm 0,04^{c}$ & $0,44 \pm 0,025^{c}$ & $3,57 \pm 0,33^{\mathrm{a}}$ \\
\hline & $(3,00-3,00)(n: 1)$ & & $(0,22-0,32)$ & $(0,37-0,50)$ & $(3,22-4,06)$ \\
\hline \multirow{2}{*}{ Doğu Anadolu } & $4,50 \pm 3,43$ & \multirow{2}{*}{$<L O D$} & $0,34 \pm 0,04^{c}$ & $0,27 \pm 0,02^{\mathrm{d}}$ & $4,61 \pm 1,10^{b}$ \\
\hline & $(1,50-8,25)(n: 3)$ & & $(0,30-0,41)$ & $(0,187-0,34)$ & $(3,76-6,46)$ \\
\hline
\end{tabular}

$a, b, c$ d. Aynı sütunda farklı harflerle gösterilen gruplar arasındaki fark istatistiki olarak önemlidir $(p<0,05)$.

Tablo 10. Üçüncü dönem (yaz) numunelerde tespit edilen metallerin bölgelere göre düzeyleri

\begin{tabular}{|c|c|c|c|c|c|}
\hline $\begin{array}{c}\text { Metal } \\
\text { / } \\
\text { Bölge }\end{array}$ & $\begin{array}{c}\text { Pb (ppb) } \\
\text { Ort. } \pm \text { SD } \\
\text { (En alt-En üst) }\end{array}$ & $\begin{array}{c}\text { Cd (ppb) } \\
\text { Ort. } \pm \text { SD } \\
\text { (En alt-En üst) }\end{array}$ & $\begin{array}{c}\text { Fe (ppm) } \\
\text { Ort. } \pm \text { SD } \\
\text { (En alt-En üst) }\end{array}$ & $\begin{array}{c}\text { Cu (ppm) } \\
\text { Ort. } \pm \text { SD } \\
\text { (En alt-En üst) }\end{array}$ & $\begin{array}{c}\text { Zn (ppm) } \\
\text { Ort. } \pm \text { SD } \\
\text { (En alt-En üst) }\end{array}$ \\
\hline \multirow{2}{*}{ İç Anadolu } & $7,35 \pm 10,28$ & \multirow{2}{*}{$<\mathrm{LOD}$} & $0,36 \pm 0,02^{a}$ & $0,10 \pm 0,06^{a}$ & $3,44 \pm 0,83^{\mathrm{ab}}$ \\
\hline & $(0,75-25,50)$ & & $(0,33-0,39)$ & $(0,03-0,20)$ & $(2,48-4,61)$ \\
\hline \multirow{2}{*}{ Marmara } & $12,45 \pm 12,46$ & \multirow{2}{*}{$<\mathrm{LOD}$} & $0,44 \pm 0,04^{c}$ & $0,21 \pm 0,09^{a b}$ & $3,28 \pm 0,28^{\mathrm{ab}}$ \\
\hline & $(3,75-34,50)$ & & $(0,38-0,49)$ & $(0,10-0,33)$ & $(2,84-3,55)$ \\
\hline \multirow{2}{*}{ Ege } & $9,15 \pm 4,05$ & \multirow{2}{*}{$<$ LOD } & $0,35 \pm 0,07^{a}$ & $0,15 \pm 0,17^{\mathrm{ab}}$ & $2,93 \pm 0,42^{\mathrm{ab}}$ \\
\hline & $(5,25-15,75)$ & & $(0,24-0,44)$ & $(0,02-0,43)$ & $(2,24-3,36)$ \\
\hline \multirow{2}{*}{ Akdeniz } & $4,50 \pm 1,91$ & \multirow{2}{*}{$<$ LOD } & $0,21 \pm 0,09^{b}$ & $0,07 \pm 0,03^{a}$ & $2,55 \pm 0,70^{a}$ \\
\hline & $(3,00-7,50)$ & & $(0,14-0,36)$ & $(0,02-0,13)$ & $(1,92-3,46)$ \\
\hline \multirow{2}{*}{ Karadeniz } & $5,70 \pm 5,2$ & \multirow{2}{*}{$<L O D$} & $0,22 \pm 0,02^{b}$ & $0,52 \pm 0,09 c$ & $3,52 \pm 0,71^{b}$ \\
\hline & $(2,25-15,00)$ & & $(0,19-0,26)$ & $(0,37-0,59)$ & $(2,66-4,30)$ \\
\hline \multirow{2}{*}{ Doğu Anadolu } & $2,70 \pm 3,95$ & \multirow{2}{*}{$<$ LOD } & $0,18 \pm 0,03^{b}$ & $0,32 \pm 0,11^{b}$ & $3,37 \pm 0,79^{a b}$ \\
\hline & $(0,75-9,75)$ & & $(0,13-0,23)$ & $(0,04-0,64)$ & $(2,06-4,03)$ \\
\hline
\end{tabular}

$a, b, c$, d. Aynı sütunda farklı harflerle gösterilen gruplar arasındaki fark istatistiki olarak önemlidir $(p<0,05)$. 
Tablo 11. Dördüncü dönem (sonbahar) numunelerde tespit edilen metallerin bölgelere göre düzeyleri

\begin{tabular}{|c|c|c|c|c|c|}
\hline $\begin{array}{c}\text { Metal } \\
/ \\
\text { Bölge }\end{array}$ & $\begin{array}{c}\text { Pb (ppb) } \\
\text { Ort. } \pm \text { SD } \\
\text { (En alt-En üst) }\end{array}$ & $\begin{array}{c}\text { Cd (ppb) } \\
\text { Ort. } \pm \text { SD } \\
\text { (En alt-En üst) }\end{array}$ & $\begin{array}{c}\text { Fe (ppm) } \\
\text { Ort. } \pm \text { SD } \\
\text { (En alt-En üst) }\end{array}$ & $\begin{array}{c}\text { Cu (ppm) } \\
\text { Ort. } \pm \text { SD } \\
\text { (En alt-En üst) }\end{array}$ & $\begin{array}{c}\mathrm{Zn} \text { (ppm) } \\
\text { Ort. } \pm \text { SD } \\
\text { (En alt-En üst) }\end{array}$ \\
\hline \multirow{2}{*}{ İç Anadolu } & $8,55 \pm 5,50^{\mathrm{a}}$ & \multirow{2}{*}{$<L O D$} & $0,28 \pm 0,07^{a}$ & $0,25 \pm 0,19^{a b}$ & $3,30 \pm 0,40^{\mathrm{ab}}$ \\
\hline & $(3,75-18,00)$ & & $(0,22-0,39)$ & $(0,11-0,54)$ & $(2,90-3,85)$ \\
\hline \multirow{2}{*}{ Marmara } & $17,25 \pm 6,64^{b}$ & \multirow{2}{*}{$<L O D$} & $0,30 \pm 0,05^{\mathrm{a}}$ & $0,41 \pm 0,15^{b}$ & $3,46 \pm 0,52^{\mathrm{abc}}$ \\
\hline & $(10,50-26,25)$ & & $(0,22-0,34)$ & $(0,21-0,56)$ & $(2,76-4,16)$ \\
\hline \multirow{2}{*}{ Ege } & $7,80 \pm 2,98^{\mathrm{a}}$ & \multirow{2}{*}{$<L O D$} & $0,27 \pm 0,06^{\mathrm{ab}}$ & $0,15 \pm 0,10^{\mathrm{a}}$ & $4,20 \pm 0,48^{b c}$ \\
\hline & $(5,25-12,00)$ & & $(0,18-0,32)$ & $(0,2-0,26)$ & $(3,82-5,02)$ \\
\hline \multirow{2}{*}{ Akdeniz } & $9,15 \pm 3,84^{a}$ & \multirow{2}{*}{$<L O D$} & $0,15 \pm 0,34^{c}$ & $0,28 \pm 0,23^{a b}$ & $2,92 \pm 1,36^{a}$ \\
\hline & $(3,00-13,50)$ & & $(0,11-0,20)$ & $(0,03-0,53)$ & $(0,72-4,00)$ \\
\hline \multirow{2}{*}{ Karadeniz } & $8,70 \pm 3,16^{a}$ & \multirow{2}{*}{$<L O D$} & $0,12 \pm 0,01^{c}$ & $0,35 \pm 0,21^{\mathrm{ab}}$ & $4,48 \pm 0,40^{c}$ \\
\hline & $(3,75-11,25)$ & & $(0,10-0,13)$ & $(0,06-0,53)$ & $(3,88-4,89)$ \\
\hline \multirow{2}{*}{ Doğu Anadolu } & $10,80 \pm 3,77^{a}$ & 0,46 & $0,19 \pm 0,05^{\mathrm{bc}}$ & $0,22 \pm 0,04^{\mathrm{ab}}$ & $3,93 \pm 0,85^{\mathrm{abc}}$ \\
\hline & $(0,75-1,50)$ & $(\mathrm{n}: 1)$ & $(0,04-0,16)$ & $(0,12-0,56)$ & $(2,24-5,02)$ \\
\hline
\end{tabular}

$a, b, c$, d. Aynı sütunda farklı harflerle gösterilen gruplar arasındaki fark istatistiki olarak önemlidir $(p<0,05)$.

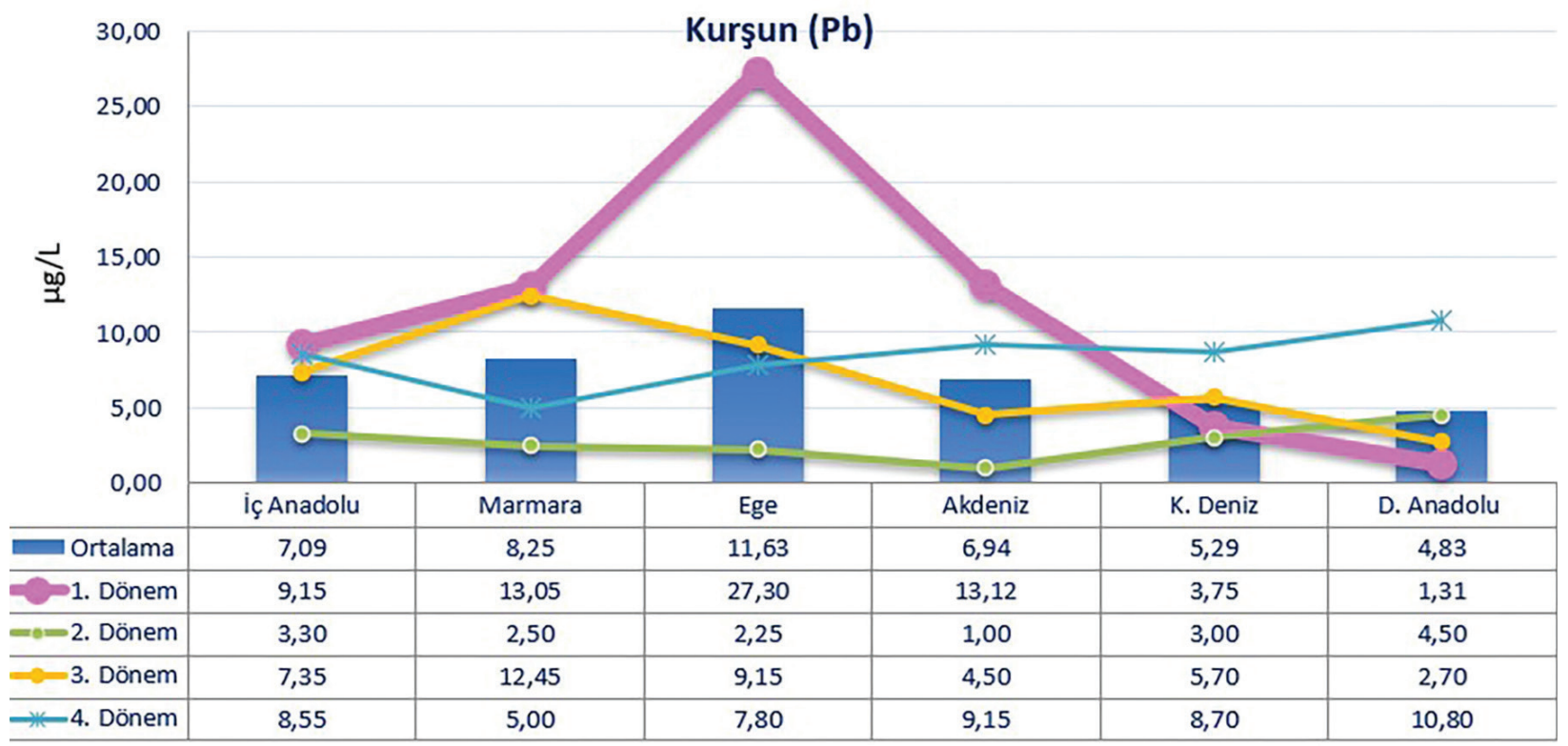

Şekil 1. Kurşun yönünden 1, 2, 3 ve 4. dönemlerde tespit edilen ortalama değerler $(\mu \mathrm{g} / \mathrm{L})$ 


\section{Kadmiyum (Cd)}

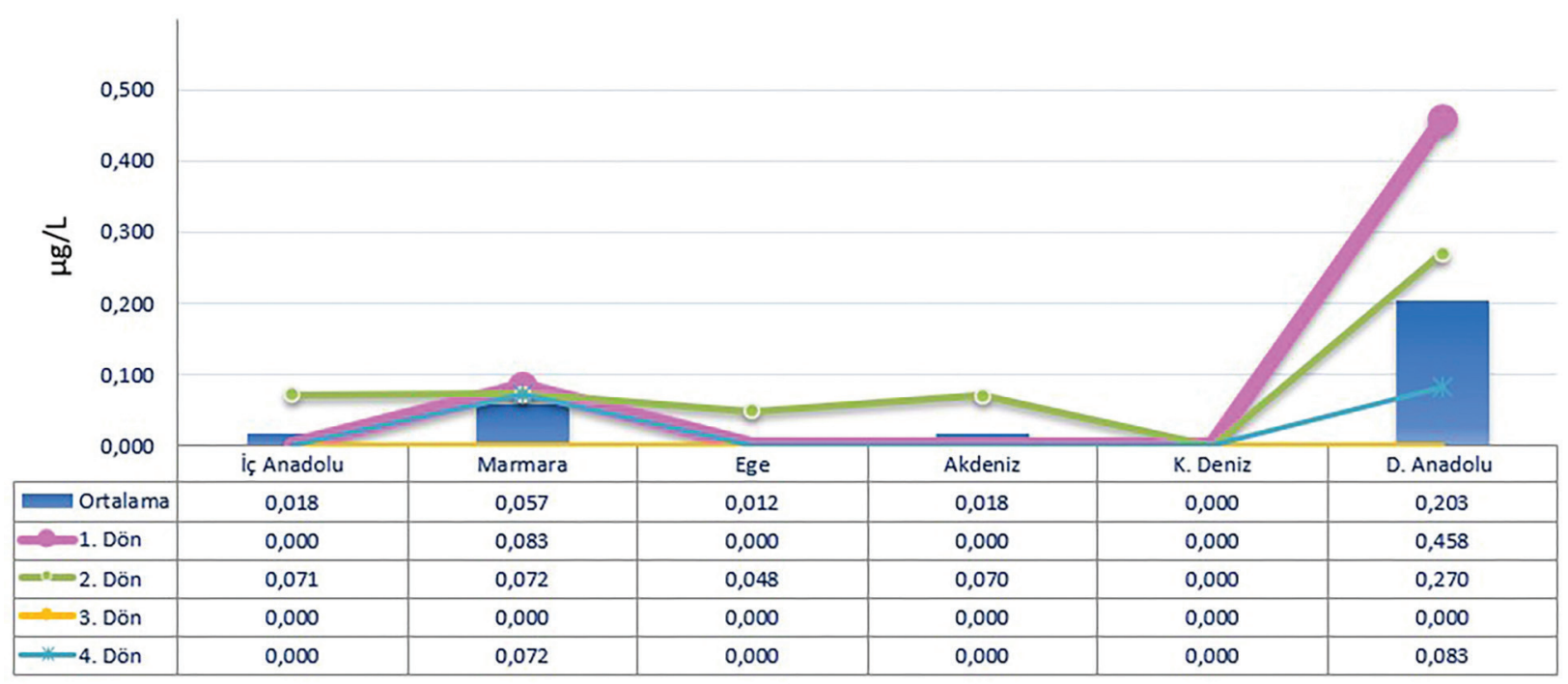

Şekil 2. Kadmiyum yönünden 1, 2, 3 ve 4. dönemlerde tespit edilen ortalama değerler ( $\mu \mathrm{g} / \mathrm{L})$

Demir (Fe)

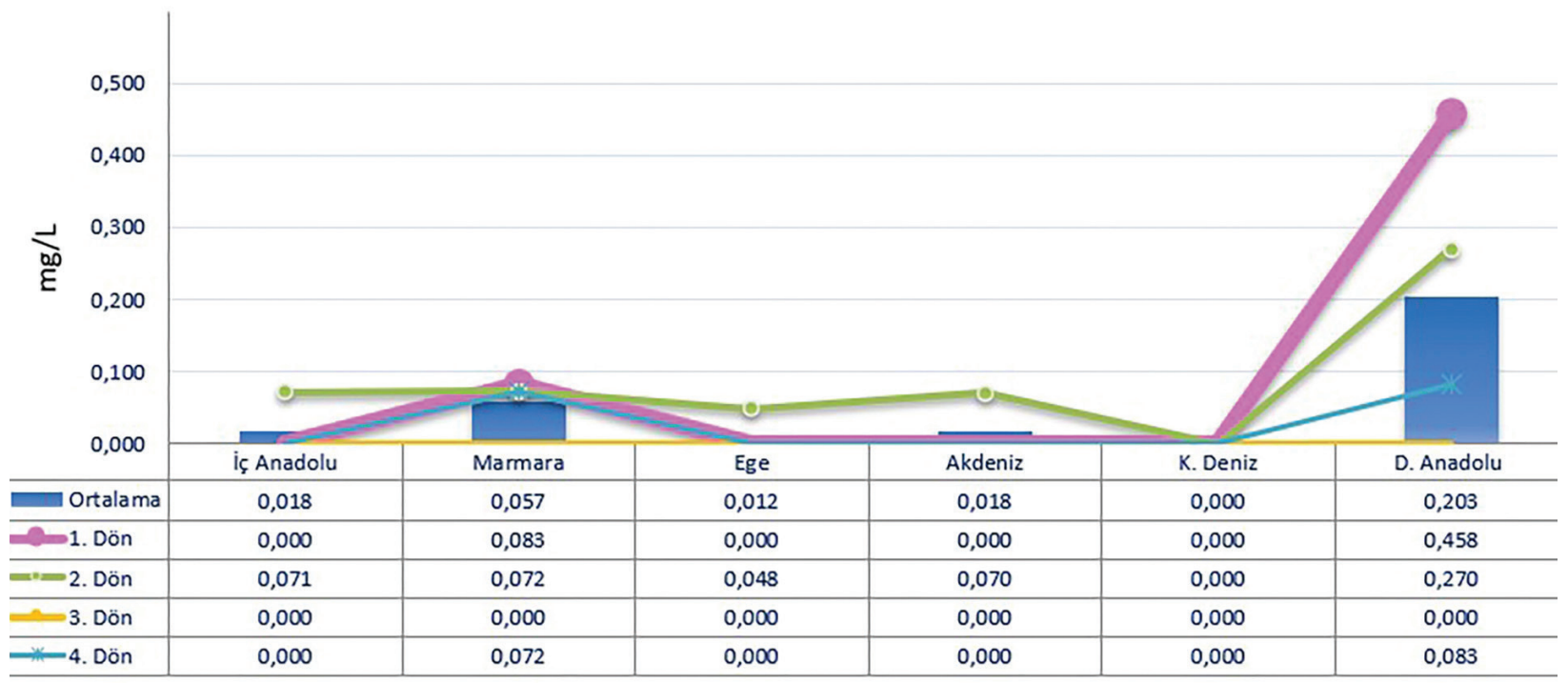

Şekil 3. Demir yönünden 1, 2, 3 ve 4. dönemlerde tespit edilen ortalama değerler (mg/L) 


\section{Bakır (Cu)}

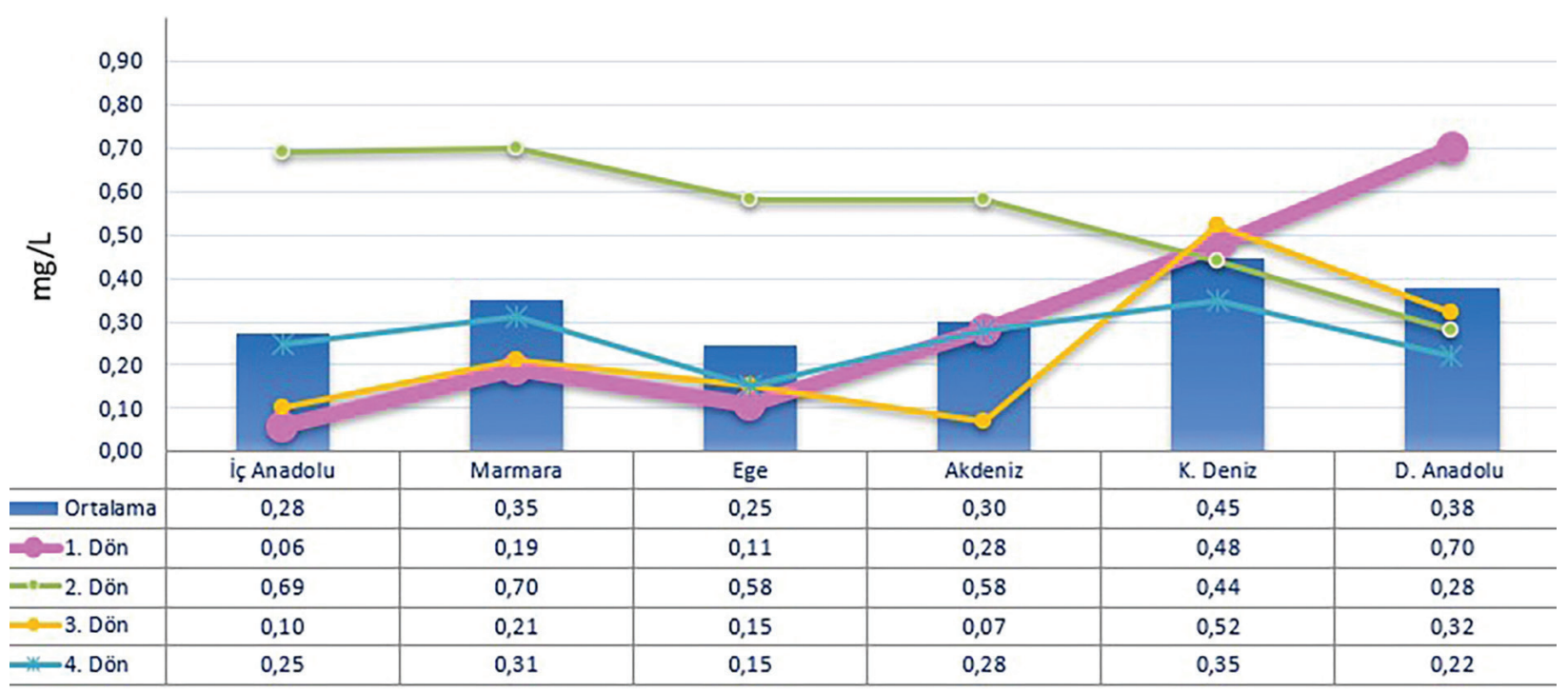

Şekil 4. Bakır yönünden 1, 2, 3 ve 4. dönemlerde tespit edilen ortalama değerler (mg/L)

\section{Çinko $(\mathrm{Zn})$}

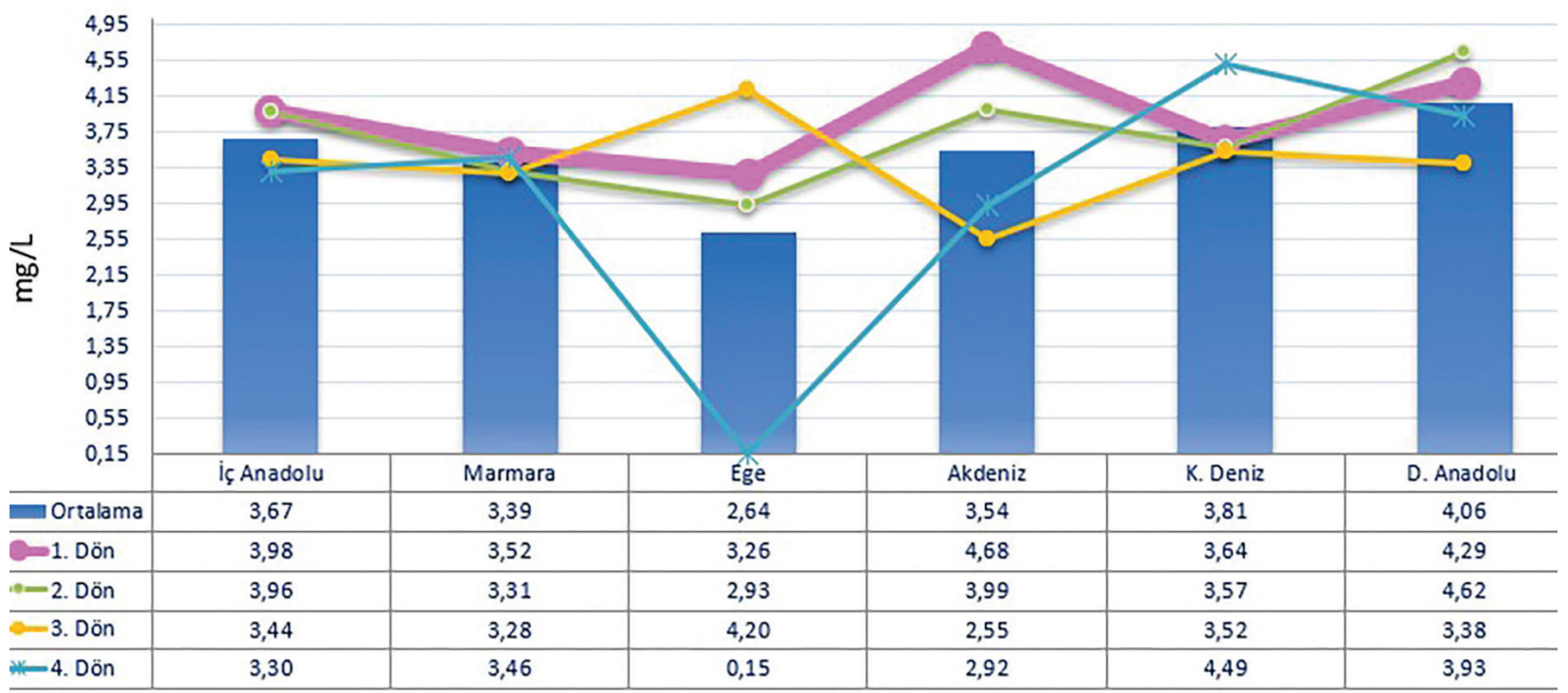

Şekil 5. Çinko yönünden 1, 2, 3 ve 4. dönemlerde tespit edilen ortalama değerler (mg/L)

\section{Tartışma ve Sonuç}

Hızlı nüfus artışı ve endüstriyel faaliyetlere bağlı olarak, çevre ve besinsel kirlenme önemli halk sağlığı ve tarımsal problemleri beraberinde getirmektedir. Hayvan ve insan beslenmesinde önemli olan bazı besin maddeleri, canlılara zarar verebilecek düzeylerde metal kalıntıları içerebilmektedir. Fabrika baca gazlarından ve maden ocaklarından çevreye, atmosfere, suya ve toprağa dolayısıyla insan ve hayvan besin zincirine toksik maddelerin karışımı mümkündür. Toksik element ve ağır metaller boya, otomotiv ve oyuncak sektörleri, inşaat, trafik ve metal endüstrileri ile tarımsal gübre yapımında yoğun olarak kullanılmaktadır (Vıcıl 2012). 
Ülkemizde Ulusal Kalıntı İzleme Planında, B3c-Kimyasal Elementler kapsamında sadece kurşun düzeyleri konusunda izleme yapılmaktadır (Anon 2011b).

2006 yılı Ülkemizde Ulusal Kalıntı İzleme Planı kapsamında ağır metaller (Kurşun) için, 51 numune alınması planlanmış, 44 numune analiz edilmiş ve bunlardan 8'i Pb yönünden Gıda Maddelerindeki Bulaşanların Maksimum Limitleri Hakkında Tebliğde kabul edilen $20 \mu \mathrm{g} / \mathrm{L}$ olan maksimum kalıntı limitini aştığı belirlenmiştir. Geri izleme için yeni alınan numunelerde ise $\mathrm{Pb}$ düzeylerinin maksimum kalıntı limitlerini aşmadığı görülmüştür (Anon 2011c).

Bu çalışma kapsamında gerçekleştirilen analizlerde Türkiye genelinde 107 örneğe ait ortalama kurşun düzeyleri 0,008 $\pm 0,009 \mathrm{mg} / \mathrm{L}$ bulundu. Örneklerdeki en yüksek kurşun değeri ise $0,059 \mathrm{mg} / \mathrm{L}$ olarak tespit edildi. Analiz edilen örnekten 10'unun $(\% 8,3) \mathrm{Pb}$ yönünden Gıda Maddelerindeki Bulaşanların Maksimum Limitleri Hakkında Tebliğde ve Avrupa Birliği 1881/2006 EC direktiflerinde kabul edilen $0,02 \mathrm{mg} / \mathrm{L}$ olan maksimum kalıntı limitlerini aştığı ancak genel $\mathrm{Pb}$ ortalamasının bu değerin altında olduğu görüldü. Diğer metaller yönünden herhangi bir kalıntı limiti belirlenmediği için bu yönde bir değerlendirme yapılamadı.

Bölgeler arası değerlendirmede istatistiki açıdan önemli farklılıklar belirlendi. En yüksek ortalama $\mathrm{Pb}$ değeri 12,29 $\pm 9,46 \mu \mathrm{g} / \mathrm{L}$ ile Marmara Bölgesinde, en düşük ortalama $\mathrm{Pb}$ değeri ise $5,07 \pm 4,95 \mu \mathrm{g} / \mathrm{L}$ ile Doğu Anadolu Bölgesinde tespit edildi. Kurşun ortalama değeri bölgelere göre sıralandığında miktar yönünden azalan sırayla Marmara> Ege> Akdeniz > İç Anadolu> Karadeniz> Doğu Anadolu Bölgesi şeklinde tespit edildi.

Dönemler açısından değerlendirildiğinde ise en yüksek ortalama $\mathrm{Pb}$ değeri 11,57 $\pm 13,69 \mu \mathrm{g} / \mathrm{L}$ ile birinci dönemde (kış), en düşük ortalama $\mathrm{Pb}$ değeri ise 2,76 $\pm 2,16 \mu \mathrm{g} / \mathrm{L}$ ile ikinci dönemde (ilkbahar) tespit edildi. Pb ortalama değeri dönemlere göre sıralandığında miktar yönünden azalan sırayla kış> sonbahar > yaz> ilkbahar şeklinde ortaya çıktı.

Kadmiyum yönünden çeşitli Avrupa ülkelerinde belirlenen maksimum kalıntı limitlerinin altında kaldığı belirlendi. Kirliliğin insan sağlığı açısından tehdit edici seviyede olmadığı anlaşıldı. $\mathrm{Cu}, \mathrm{Fe}$, ve $Z n$ yönünden elde edilen sonuçlar değerlendirildiğinde ise bu metallerin de normal sınırlar içerisinde olduğu ve insan sağlığı yönünden risk oluşturacak düzeyde olmadığı tespit edildi.

Sütlerde kalite değerlendirmesi ve çevresel kirliliğin belirlenmesi amacıyla ülkemizde farklı araştı- rıcılar tarafından bazı çalışmalar Gültekin (1998); Algan (2002); Özrenk (2002); Şenol ve Özdemir (2003); Temurci (2006); Ayar ve ark. (2007); Temiz ve Soylu (2012); Kaptan ve ark. (2016); Bakırcıoğlu ve ark. (2018) yapılmıştır.

Gültekin (1998) tarafından yapılan çalışmada, Bursa ili ve çevresinden alınan 75 süt örneğinde trafik yoğun bölgelerde, sanayi bölgelerinde ve kırsal bölgelerde olma durumuna göre bazı mineral madde ve ağır metallerin tespiti yapılmıştır. Araştırma sonucunda, analiz edilen süt örneklerinde $\mathrm{Pb}$ düzeyi, trafik yoğun bölgelerde $0,032 \pm 0,002 \mathrm{mg} / \mathrm{L}(0,023-$ $0,040 \mathrm{mg} / \mathrm{L})$, sanayi bölgelerinde $0,049 \pm 0,001 \mathrm{mg} / \mathrm{L}$ $(0,042-0,058 \mathrm{mg} / \mathrm{L})$ ve kırsal bölgelerde $0,018 \pm 0,00$ $\mathrm{mg} / \mathrm{L}(0,017-0,021 \mathrm{mg} / \mathrm{L})$, Cu düzeyi trafik yoğun bölgelerde $0,58 \pm 0,026 \mathrm{mg} / \mathrm{L} \quad(0,47-0,70 \mathrm{mg} / \mathrm{L})$, sanayi bölgelerinde $0,96 \pm 0,038 \mathrm{mg} / \mathrm{L} \quad(0,77-0,96$ $\mathrm{mg} / \mathrm{L})$ ve kırsal bölgelerde 0,39 $\pm 0,012 \mathrm{mg} / \mathrm{L}(0,33-$ $0,45 \mathrm{mg} / \mathrm{L})$, Fe düzeyi trafik yoğun bölgelerde $1,78 \pm 0,16 \mathrm{mg} / \mathrm{L}(1,26-2,60 \mathrm{mg} / \mathrm{L})$, sanayi bölgelerinde 4,27 $\pm 0,26 \mathrm{mg} / \mathrm{L}(2,65-5,30 \mathrm{mg} / \mathrm{L})$ ve kırsal bölgelerde $1,01 \pm 0,029 \mathrm{mg} / \mathrm{L}(0,80-1,01 \mathrm{mg} / \mathrm{L}), \mathrm{Zn}$ düzeyi trafik yoğun bölgelerde $4,49 \pm 0,39 \mathrm{mg} / \mathrm{L}(2,30-6,46$ $\mathrm{mg} / \mathrm{L})$, sanayi bölgelerinde $5,01 \pm 0,26 \mathrm{mg} / \mathrm{L}(3,75-$ $6,45 \mathrm{mg} / \mathrm{L})$ ve kırsal bölgelerde $3,77 \pm 0,18 \mathrm{mg} / \mathrm{L}$ $(2,60-4,72 \mathrm{mg} / \mathrm{L})$ olarak belirlenmiş, sanayi bölgesinden alınan örneklerde $\mathrm{Fe}$ ve $\mathrm{Cu}$ miktarı normal değerlerin üzerinde bulunmuştur. $\mathrm{Pb}$ için ise sanayi ve trafik yoğun bölgelerden alınan örneklerdeki $\mathrm{Pb}$ miktarı için Avrupa Birliği EC 315/93 direktiflerinde belirtilen $0.02 \mathrm{mg} / \mathrm{L}^{\prime} ı$ üzerinde bulunmuştur.

Algan (2002) tarafından yapılan çalışmada Konya yöresinden alınan 61 süt örneğinde bazı ağır metal miktarlarının tespitini yapmışlardır. Analiz edilen

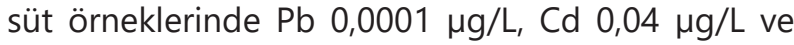
Zn 2,66 mg/L düzeylerinde tespit etmişlerdir. Yapılan bu çalışmada $\mathrm{Pb}, \mathrm{Cd}$ ve $\mathrm{Zn}$ yönünden normal sınırlar içerisinde olup bir kirlilik tespit edilmemiştir.

Özrenk (2002) tarafından yapılan Van ili ve çevre ilçelerinde üretilen inek sütlerinin ağır metal kirliliği ve bazı mineral içeriklerinin belirlenmesi çalışmasında, yaz mevsiminde 130, kış mevsiminde 130 toplam 260 örnekte çalışılmıştır. Analiz edilen süt örneklerinin 189 'unda ortalama $0,002 \pm 0.01 \mathrm{mg} / \mathrm{L}(0.001-$ $0.007) \mathrm{Pb}$ tespit edilmiştir. Fe düzeyi $0,31 \pm 0,17$ $\mathrm{mg} / \mathrm{L}(0,050-0,890)$, Cu düzeyi $0,182 \pm 0,157 \mathrm{mg} / \mathrm{L}$ $(0,10-0,830)$ ve $\mathrm{Zn} 3,00 \pm 1,09 \mathrm{mg} / \mathrm{L}(0,17-5,28)$ olarak tespit edilmiştir. Analiz edilen örneklerde ilçeler arası farklılık bulunmamasına rağmen, mevsimsel değişiklik tespit edilmiş ve bunun sebebinin Van gibi kış günlerinin soğuk ve uzun geçtiği bir ilde yakılan soba ve kaloriferlerin yanma süresinin uzun olması, kullanılan kömür miktarının fazla ve kalitesiz olması 
gösterilmiştir. Özellikle $\mathrm{Pb}, \mathrm{Fe}, \mathrm{Cu}$ ve $\mathrm{Zn}$ düzeylerinin kışlık yemlerde daha yüksek olduğu ve bu artışın kışlık sütlerde de gözlemlendiği bildirilmiştir.

Şenol ve Özdemir (2003) tarafından yapılan Sakarya illi ve çevre ilçelerinde trafik yoğunluğu farkIı (az yoğun, orta yoğun, çok yoğun) 3 bölgeden alınan 45 adet süt numunesinde çinko düzeyleriyle ilgili çalışmada $\mathrm{Zn}$ düzeyleri sırasıyla, $3,35 \mathrm{mg} / \mathrm{L}$ $(1,26-6,56), 3,70 \mathrm{mg} / \mathrm{L}(1,79-5,24), 3,85 \mathrm{mg} / \mathrm{L}(2,78-$ $5,41)$ tespit edilmiştir.

Temurci (2006) tarafından Ankara'da tüketime sunulan süt ve beyaz peynirlerde yapılan bir çalışmada 36 süt örneği kullanılmış, bu örneklerin hiç birinde $\mathrm{Pb}$ 'ye rastlanılmamıştır. $\mathrm{Cd}$ düzeyi ise $0,11 \pm 0,03 \mathrm{mg} / \mathrm{L}(0-1,16)$, bakır düzeyi $4,30 \pm 0,36$ $\mathrm{mg} / \mathrm{L}(1,5-13,66)$, Fe düzeyi ise $52,19 \pm 4,09 \mathrm{mg} / \mathrm{L}$ $(17,16-128,42)$ bulunmuştur.

Ayar ve ark. (2007) tarafından Konya'da tüketime sunulan süt ve ürünleri değişik süt işletmelerinden ve diğer satıcı marketlerden 4 ay süreyle farklı olacak şekilde 2 şer örnek, her birinden 8 adet olacak şekilde toplam 96 örnek alınmıştır. $\mathrm{Pb}$ düzeyi $0.103 \pm 0.14 \mathrm{mg} / \mathrm{L}, \quad C d$ düzeyi ise $0.017 \pm 0.010 \mathrm{mg} / \mathrm{L}$ olarak tespit edilmiştir.

Temiz ve Soylu (2012) tarafından Samsun Iilinde 144 adet örnekte indüktif eşleşmiş plazma kütle spektrometre ile gerçekleştirilen çalışmada 0.028$0.068 \mathrm{mg} / \mathrm{L}$ aralığında $\mathrm{Pb}, 0.001-0.013 \mathrm{mg} / \mathrm{L}$ aralığında $\mathrm{Cd}, 0.618-1.889 \mathrm{mg} / \mathrm{L}$ aralığında $\mathrm{Cu}, 0.12-$ $0.64 \mathrm{mg} / \mathrm{L}$ aralığında Fe, 11.597-14.907 mg/L aralığında $\mathrm{Zn}$ tespit edildiği, $\mathrm{Pb}, \mathrm{Cd}$ ve $\mathrm{Cu}$ yönünden yaz döneminde toplanan örneklerin kış dönemine göre daha yüksek olduğu, $\mathrm{Pb}, \mathrm{Cu}, \mathrm{Zn}$ yönünden bu sütlerin güvenilir olmadığı, çalışma alanındaki çevresel bulaşmanın yoğun endüstriye atfedildiği bildirilmiştir.

Kaptan ve ark. (2016) tarafından Çanakkale Biga İlçesinde 3 farklı bölge (yoğun endüstriye yakın, gıda üreten fabrikalara yakın, otoyola yakın) ve 3 farklı dönemde alınan örneklerde İndüklenmiş Eşleşmiş Plazma Atomik Emisyon Spektroskopi ile gerçekleştirilen çalışmada (0.503-1.859 mg/L arasında değişen düzeylerde olmak üzere $1.011 \pm 0.36 \mathrm{mg} / \mathrm{L}$ ortalama $\mathrm{Pb}$ tespit edildiği, en yüksek kurşun düzeyinin otoyola yakın olan bölgedeki süt örneklerinde bulunduğu, 0.027-0.397 0 mg/L Cd $(0.124 \pm 0.11$ $\mathrm{mg} / \mathrm{L}$ ortalama), $0.755-3.046 \mathrm{mg} / \mathrm{L}$ olmak üzere $1.9005 \mathrm{mg} / \mathrm{L}$ ortalama $\mathrm{Zn}$ ve Cd'nin yine yoğun trafik bölgesindeki ineklerden toplanan örneklerde tespit edildiği, en yüksek Cu düzeyinin $1.564 \mu \mathrm{g} / \mathrm{L}$ ile yaz döneminde tespit edildiği, sütteki Cu düzeylerinin yaz sezonunda bitki koruma ürünü kullanımı ve endüstriyel emisyonlar nedeniyle artabileceği, lipit oksidasyonundaki katalitik etkisi yönünden süt ürünlerinde potansiyel risk oluşturan $\mathrm{Fe}$ için en yüksek konsantrasyonun 4.207 mg/L olarak yoğun trafik bölgesindeki ineklerden toplanan örneklerde tespit edildiği bildirilmiştir.

Bakırcıoğlu ve ark. (2018) tarafından İndüklenmiş Eşleşmiş Plazma Optik Emisyon Spektroskopi ile Edirne IIlinden toplanan 90 adet süt örneğinde gerçekleştirilen çalışmada doğal ürünlerde ortalama $0.138 \pm 0.016 \mathrm{mg} / \mathrm{L} \mathrm{Cu}, 3.1 \pm 0.5 \mathrm{mg} / \mathrm{L} \mathrm{Fe}, 3.4 \pm 0.7$ $\mathrm{mg} / \mathrm{L} \mathrm{Zn}$, marketten alınan ticari örneklerde $0.138 \pm$ $0.041 \mathrm{mg} / \mathrm{L} \mathrm{Cu}, 2.2 \pm 1.3 \mathrm{Fe}, 3.5 \pm 0.7 \mathrm{mg} / \mathrm{L} \mathrm{Zn}$ tespit edildiği, bu bilgilere göre ticari ürünlerde doğal ürünlere göre daha yüksek düzeylerde bulunduğu bildirilmiştir.

Bu çalışmada elde edilen sonuçlar $\mathrm{Pb}$ yönünden Algan (2002); Özrenk (2002); Temurci (2006) ve Kaptan ve ark. (2016) tarafından yapılan çalışmalardan yüksek; Gültekin (1998); Ayar ve ark. (2007) ile Temiz ve Soylu (2012) tarafından yapılan çalışmalardan ise düşük bulundu. Gültekin (1998) tarafından yapılan çalışmada elde edilen trafik yoğun bölge ve sanayi bölgesi örnekleri, Ayar ve ark. (2007) ve Temiz ve Soylu (2012) tarafından analiz edilen tüm örneklerin kurşun düzeyleri kabul edilebilir limitin üzerindedir Kurşun yönünden kabul edilebilir maksimum limitlerin üzerinde tespit edilen 10 örneğin dördünün Marmara, üçünün Ege, ikisinin İç Anadolu ve birinin de Akdeniz Bölgesine ait sütlerde tespit edilmesi, trafik açısından yoğun bölgeler ve sanayi bölgeleri örneklerindeki ağır metal kirliliği ile uyumlu bulundu. Sütlerde metal düzeyi toprağın yapısı, bitki örtüsü, iklim şartları ve endüstriyel faaliyet şartlarından etkilenmektedir. Dolayısı ile çalışmalar arasında böyle bir farklılığın olması bu sebepler bağlı olarak değerlendirilebilir.

Kadmiyum yönünden Özrenk (2002) tarafından yapılan çalışmadaki elde edilen sonucun yaklaşık iki katı yüksek; Temurci (2006); Ayar ve ark. (2007); Temiz ve Soylu (2012) ve Kaptan ve ark. (2016) tarafından yapılan çalışma sonuçlardan ise oldukça düşük bulundu.

Demir yönünden Özrenk (2002) ve Temiz ve Soylu (2012) tarafından yapılan çalışmadaki elde edilen sonuçlardan biraz düşük; Gültekin (1998); Şenol (2004) tarafından yapılan çalışmalardaki elde edilen sonuçlardan düşük, Temurci (2006); Kaptan ve ark. (2016) ve Bakırcıoğlu ve ark. (2018) tarafından yapılan çalışma sonuçlardan ise oldukça düşük bulundu. 
Bakır yönünden Özrenk (2002) tarafından yapılan çalışmadaki elde edilen sonuçlardan yüksek; Gültekin (1998); Temiz ve Soylu (2012) ve Bakırcıoğlu ve ark. (2018) tarafından yapılan çalışmada elde edilen kırsal bölge sonuçları ile uyumlu, trafik yoğun bölge ve sanayi bölgesi örneklerinden düşük bulundu.

Çinko yönünden Gültekin (1998); Özrenk (2002); Şenol ve Özdemir (2003) ve Bakırcıoğlu ve ar. (2018) tarafından yapılan çalışmada elde edilen kırsal bölge sonuçları ile uyumlu; trafik yoğun bölge ve sanayi bölgesi örnekleri ile Temiz ve Soylu (2012) düşük, Kaptan ve ark. (2016) çalışmalarından yüksek bulundu.

Uluslararası alanda sütlerde kalite değerlendirmesine yönelik veya çevresel kirliliğin belirlenmesi amacıyla yapılmış çok sayıda çalışma Vidovic ve ark. (1997); Lawal ve ark. (2006); Bilandžić ve ark. (2016); Qu ve ark. (2018); Norouzirad ve ark. (2018) ve Peinado ve ark. (2020) vardır.

Vidovic ve ark. (1997) tarafından Sırbistan'da yapılan bir çalışmada 1996 ve 1997 yılları arasında toprak, kuru ot ve süt örneklerindeki $\mathrm{Pb}, \mathrm{Cd}$ ve $\mathrm{Zn}$ düzeylerini belirlemişlerdir.1996 yılında 96 süt örneğinde, $\mathrm{Pb}$ düzeyi $0,078 \pm 0,042 \mu \mathrm{g} / \mathrm{l}, 1997$ yılında 0,089 $\pm 0,046 \mu \mathrm{g} / \mathrm{l}$, Cd düzeyi 1996 yılında 0,008 $\pm 0,004$ $\mu \mathrm{g} / \mathrm{l}, 1997$ yılında $0,007 \pm 0,003 \mu \mathrm{g} / \mathrm{l}$ ve $\mathrm{Zn}$ düzeyi 1996 yılında 1,88 $\pm 0,5 \mu \mathrm{g} / \mathrm{l}, 1997$ yılında 1,64 $\pm 0,4$ $\mu \mathrm{g} / \mathrm{l}$ düzeylerinde tespit edilmiş ve toprak, kuru ot ve süt arasında doğru orantı tespit etmişlerdir.

Lawal ve ark. (2006) tarafından Nijerya'da merada otlatılan sığırlara ait 24 süt örneğini $\mathrm{Pb}, \mathrm{Cd}$ ve $\mathrm{Cu}$ yönünden incelemişlerdir. $\mathrm{Pb}$ düzeyi $0,53 \pm 0,29$ $\mathrm{mg} / \mathrm{L}, \mathrm{Cd}$ düzeyi $0,26 \pm 0,13 \mathrm{mg} / \mathrm{L}$ ve $\mathrm{Cu}$ düzeyi $0,062 \pm 0,026 \mathrm{mg} / \mathrm{L}$ bulunmuştur. Bulunan sonuçlara göre, $\mathrm{Pb}$ düzeyinin $\mathrm{WHO}$ tarafından belirlenen günlük kabul edilebilir en fazla doz olan $0,05 \mathrm{mg} / \mathrm{L}$ vücut ağırlığı ve $\mathrm{Cd}$ düzeyinin de WHO tarafından belirlenen günlük kabul edilebilir en fazla doz olan $0,02-$ 0,06 mg/L vücut ağırlığı geçtiğini bildirmişlerdir.

Bilandžić ve ark. (2016) tarafından yayınlanan, Hırvatistan'ın kırsal alanlarındaki 249 adet inekten toplanan çiğ süt örneklerinde 2010-2014 yıllarını kapsayan, grafit fırınlı atomik absorbsiyon spektrometre ile gerçekleştirilen çalışmada kurşun miktarının $10.8-12.2 \mu \mathrm{g} / \mathrm{kg}$, en yüksek kurşun seviyesinin $131 \mu \mathrm{g} / \mathrm{kg}$ olduğu bildirilmiştir. Bu konsantrasyonların, izin verilen haftalık kurşun alımının \% 1.37 katkı sağlayacağı, bu verilere dayanarak süt tüketiminin tüketici sağlığı yönünden risk oluşturmadığı sonucuna ulaşıldığı bildirilmiştir.
Qu ve ark. (2018) tarafından Çin'de 178 adet ineğe ait sütlerde indüktif eşleşmiş plazma kütle spektrometre ile gerçekleştirilen çalışmada $1.35 \pm 0.32 \mu \mathrm{g} / \mathrm{L}$ düzeyinde kurşun tespit edildiği, kadmiyum tespit edilemediği bildirilmiştir. Tespit edilen kurşun düzeyinin tüketiciler yönünden sağlık riski oluşturmadığı bildirilmiştir. Bununla birlikte kurşun tüketimine bağlı risklerin bebekler ve genç yaştaki çocuklar için yetişkinlere göre daha ciddi olduğu ifade edilmiştir.

Norouzirad ve ark. (2018) tarafından 20152016 yıllarını kapsayan 118 adet ineğe ait sütlerde grafit fırınlı atomik absorbsiyon spektrometre ile gerçekleştirilen çalışmada ortalama $47.0 \pm 3.9 \mu \mathrm{g} /$ $\mathrm{kg}$ kurşun, $4.7 \pm 1.0 \mu \mathrm{g} / \mathrm{kg}$ kadmiyum tespit edildiği, örneklerin \% 82.2'sinin kurşun yönünden izin verilen $20 \mu \mathrm{g} / \mathrm{kg}$ limitinin üzerinde olduğu, çalışma sonuçlarına göre petrol yataklarına yakın bölgelerde kurşun ve kadmiyum maruziyeti yönünden sütlerin risk oluşturduğu belirtilerek izleme planlarına dahil edilmesi önerilmiştir.

Peinado ve ark. (2020) tarafından alevli atomik absorbsiyon spektrometre ile Peru'da La Oroya metalürjik kompleksi yakınındaki kırsal alanda yetiştirilen 20 ineğin kanlarında $0.38 \pm 0.041$, sütlerinde $0.58 \pm 0.018 \mathrm{mg} / \mathrm{L}$ kurşun tespit ettikleri, kurşun seviyesinin sütteki oranının kan konsantrasyonundan \% 54 yüksek olduğu, kadmiyum seviyelerinin kanda $0.016 \pm 0.002$, sütte $0.02 \pm 0.007 \mathrm{mg} / \mathrm{L}$ olduğu, sütteki kadmiyum oranının kandaki konsantrasyondan \% 28 yüksek olduğu bildirilmiştir. Günlük 200 ml'lik süt tüketiminin $0.12 \mathrm{mg}$ kurşun ve $0.004 \mathrm{mg} \mathrm{kad}$ miyum sağlayacağı; bu miktarların 180 gün sonra kümülatif olarak $216 \mathrm{mg}$ kurşun ve $0.72 \mathrm{mg}$ kadmiyum alımını temsil ettiği, insan tüketimi için uygun olmayan bu miktarın halk sağlığı yönünden ciddi risk oluşturduğu ifade edilmiştir.

Boudebbouz ve ark. (2021) tarafından, 2010 yıIından itibaren dünya çapında yayınlanmış 60 orijinal araştırmanın dahil edildiği sistematik derlemede en yüksek $\mathrm{Cd}$ seviyesinin Hindistan'da barit maden sahasında $12 \mathrm{mg} / \mathrm{L}$, en yüksek $\mathrm{Pb}(60 \mathrm{mg} / \mathrm{L}), \mathrm{Cu}$ (36 mg/L) seviyelerinin Hindistan'da granit ve granit gnaysdan oluşan alanlarından toplanan örneklerde, en yüksek $\mathrm{Fe}$ düzeyinin $37.02 \mathrm{mg} / \mathrm{L}$ yine Hindistan'da tespit edildiği bilgisi paylaşılmıştır.

Bu çalışmada elde edilen sonuçlar $\mathrm{Pb}$ yönünden Vidovic ve ark. (1997); Bilandžić ve ark. (2016); Qu ve ark. (2018) tarafından yapılan çalışmalardan yüksek; Lawal ve ark. (2004), Norouzirad ve ark. (2018) ile Peinado ve ark. (2020) tarafından yapılan çalışmalardan düşük bulundu. 
Kadmiyum yönünden Vidovic ve ark. (1997); Peinado ve ark. (2020) tarafından yapılan çalışmalardan yüksek; Lawal ve ark. (2004); Norouzirad ve ark. (2018); Peinado ve ark. (2020) tarafından yapılan çalışmalardan ise düşük bulundu.

Sonuçlar yurt dışı çalışmalarla karşılaştıııldığında, Sırbistan'dan yüksek bulunmasının sebebinin iklim özelliklerinin daha ılıman olması ve araştırma yapılan bölgelerin endüstriyel alanlardan uzak olması düşünülmektedir. Nijerya ve Peru'da yapılan çalışmadan düşük bulunmasının sebebi ise, Nijerya topraklarının metalleri yüksek yoğunlukta içermesi (özellikle demir ve alüminyum), petrokimya endüstrisinin gelişmiş olması ve çok sayıda rafineri bulunmasına bağlı olduğu, Peru'da yüksek bulunmasının sebebinin de büyük kapasitedeki bir metalürjik komplekse yakın olması düşünülmektedir.

Bu çalışmada elde edilen sonuçlar, bazı uluslararası limitlerle (Komisyon Direktifi EC No: 1881/2006) karşılaştırıldığında $\mathrm{Pb}$ yönünden örneklerin 10 'unun $(\% 8,3)$ maksimum kalıntı limitlerini aştığı, ancak genel ortalamanın bu değerin altında olduğu görüldü.

Süt, çeşitli nedenlerle kontaminasyonlara duyarlı bir üründür. Süt sığırlarının merada beslenmeleri sırasında toprakta doğal olarak da bulunan ağır metaller, otlara bulaşan endüstriyel kalıntılar, çeşitli pestisit kalıntıları, hayvanların tedavisinde kullanılan çeşitli hormonlar ve ilaçlar, kalitesiz yemlerden süte geçiş yapan aflatoksin ve mikotoksinler, parazitler ve deterjan kalıntıları direkt olarak süte geçebilmektedir. Süt ve ürünlerinde bulunma olasılığı yüksek olan ve tüketici tarafından fazla bilinmeyen sağlığa zararı kalıntı maddeler, toplum sağlığı açısından büyük tehlike oluşturmaktadır.

Kaliteli süt üretimi, ekonomik anlamda ve sağlık açısından çok önemlidir. Süt sığırcılığının ve süt sanayinin gelecekteki anahtarıdır. Süt üretim faaliyetlerinin muhtemel ağır metal kirliliğine yol açabilecek alanlardan uzak yerlerde yapılması daha uygun olacaktır. Ülkemizde $\mathrm{Pb}$ yönünden limit değerleri belirlenmekle birlikte $\mathrm{Cd}$ içinde limit değerinin Avrupa ülkeleri ile uyumlu olarak belirlenmesi gerekmektedir.

Gerek $\mathrm{Pb}$ gerekse diğer metallerin süt ve süt ürünlerindeki düzeyinin aşağıya çekilebilmesi için;

- Daha bilinçli ve daha kontrollü bir şekilde üretim işlemi gerçekleştirilmelidir.

- Çiftçi ve işletmecilerin bilgilendirilmesi bir zorunluluktur.

- Ağır metal kalıntılarının önemine ilişkin kamuoyu bilgilendirme çalışmaları yapılmalıdır.
- Bilgilendirmenin yanında etkin bir kontrol mekanizmasının devlet tarafından uygulanmaya konulması da bu metallerin kontaminasyonunun engellenmesinde önemli rol oynayacaktır.

- Ağır metal kalıntılarına ilişkin özellikle riskli bölgeler de göz önüne alınarak geniş ölçekte kalıntı analizleri yapılmalıdır.

- Analiz noktasında uygun laboratuvar şartları/ekipman sağlanmalıdır.

- Sadece süt üretiminin değil yem üretiminin de endüstriyel alanlardan uzak bölgelerde yapılması gereklidir.

Deney hayvanları kullanımı etik kurulu ve diğer etik kurul kararları ve izinler: Etik kurul kararına gerek bulunmamaktadır.

Maddi destek ve çıkar ilişkisi Çalışmayı maddi olarak destekleyen kişi/kuruluş yoktur ve yazarların herhangi bir çıkara dayalı ilişkisi yoktur.

\section{Kaynaklar}

Algan G. (2002) Konya yöresi sütlerinde bazı ağır metallerin incelenmesi. Yüksek lisans Tezi, Selçuk Üniversitesi Sağlık Bilimleri Enstitüsü, Konya.

Anon. (2006) Commıssion Regulation (EC) No 1881/2006 of 19 December 2006 setting maximum levels for certain contaminants in foodstuffs. Erişim adresi: https://eur-lex.europa.eu/legal-content/ EN/TXT/HTML/?uri=CELEX:32006R1881\&from=EN, Erişim tarihi: 12.02.2021

Anon. (2011a) Hayvansal Gıdalar İçin Özel Hijyen Kuralları Yönetmeliği Resmi Gazete, 27.12.2011 Tarih ve 28155 Sayı Erişim adresi: https://www.resmigazete.gov.tr/eskiler/2011/12/20111227-10.htm, Erişim tarihi: 12.02.2021

Anon. (2011b) Canlı Hayvanlar Ve Hayvansal Ürünlerde Belirli Maddeler İle Bunların Kalıntılarının İzlenmesi İçin Alınacak Önlemlere Dair Yönetmelik. T. C. Resmi Gazete, 17.12.2011 Tarih ve 28145 Sayı. Erişim adresi: https://www.resmigazete.gov.tr/eskiler/2011/12/20111217-4.htm , Erişim tarihi: 12.02.2021

Anon. (2011c) Türk Gıda Kodeksi Bulaşanlar Yönetmeliği T.C. Resmi Gazete, 29.12.2011 Tarih ve 28157 Sayı. Erişim adresi: https:// www.resmigazete.gov.tr/eskiler/2011/12/20111229M3-8.htm, Erişim tarihi: 12.02.2021

Anon. (2019) Türk Gıda Kodeksi İçme Sütleri Tebliği, (Tebliğ No: 2019/12). Resmi Gazete, 27.02.2019 Tarih ve 30699 Sayı. Erişim adresi: https://www.resmigazete.gov.tr/eskiler/2019/02/20190227-5.htm, Erişim tarihi: 12.02.2021

AOAC. (2000) Official Methods of Analysis of AOAC International. 17 th Ed., AOAC International Gaithersburg. Md, Usa Offical Method 999.10. Chapter 9 p:16

Ayar A, Sert D, Akın N. (2007) Konyada Tüketime Sunulan Süt ve Ürünlerinin Ağır Metal İçeriklerinin Belirlenmesi. Selçuk Üniversitesi Ziraat Fakültesi Dergisi. 21 (41): (2007) 58-64

Bakırcıoğlu D, Topraksever N, Yurtsever S, Kızıldere M, Bakırcıoğlu YK. (2018) Investigation of macro, micro and toxic element concentrations of milk and fermented milks products by using an inductively coupled plasma optical emission spectrometer, to improve food safety in Turkey, Microchemical Journal, Volume 136, 2018, Pages 133-138, ISSN 0026-265X, https://doi.org/10.1016/j.microc.2016.10.014

Bilandžić N, Sedak M, Čalopek B.(2016) Lead Concentrations in Raw Cow and Goat Milk Collected in Rural Areas of Croatia from 2010 
to 2014. Bull Environ Contam Toxicol 96, 645-649 (2016). https:// doi.org/10.1007/s00128-016-1749-z

Boudebbouz A, Boudalia S, Bousbia A, Habila S, Boussadia MI, Gueroui $Y$. (2021) Heavy metals levels in raw cow milk and health risk assessment across the globe: A systematic review. Science of The Total Environment, Volume 751, 141830. https://doi.org/10.1016/j.scitotenv.2020.141830.

Gültekin R. (1998) Bursa ili çevresinden alınan çiğ süt örneklerinde bazı mineral madde ve ağır metallerin tespiti üzerine bir araştırma. Yüksek Lisans Tezi, Trakya Üniversitesi Fen Bilimleri Enstitüsü, Tekirdağ.

Kaptan B, Bilgücü E, Palabıyık I, Öksüz Ö. (2016) The Effect of Environmental Factors on Heavy Metal and Mineral Compositions of Raw Milk and Water Samples. Tekirdağ Ziraat Fakültesi Dergisi, 13 (4).

Kaya S, Akar F. (1998) Metaller, diğer inorganik maddeler ve radyoetkin maddeler. Veteriner Hekimliğinde Toksikoloji. Ed.: S. Kaya, ì. Pirinçci, A. Bilgili. 1. Baskı, Medisan Yayınevi, Ankara, s. 122-138.

Kınık Ö, Uysal H R, Akbulut N. (2003) Süt ve Süt Ürünlerinde İz Elementler. E.Ü. Ziraat Fakültesi Yayınları No: 549. E.Ü.Basımevi, Bornova, İzmir, 163s.

Lawal AO, Mohammed SS, Damisa, D. (2006) Assessment of levels of Copper, Cadmium and Lead in secretion of mammary gland of cows grazed on open fields. Science World Journal. 1. 7-10. 10.4314/swj.v1i1.51689.

Norouzirad R, Montaña JRG, Pastor FM, Hosseini H, Shahrouzian A, Khabazkhoob M, Malayeri FA, Bandani HM, Paknejad M, Foroughinia B, Moghaddam AF. (2018) Lead and cadmium levels in raw bovine milk and dietary risk assessment in areas near petroleum extraction industries, Science of The Total Environment. Volume 635, Pages 308-314. https://doi.org/10.1016/j.scitotenv.2018.04.138.
Özrenk E. (2002) Van ili ve çevre ilçelerinde üretilen inek sütlerinin ağır metal kirlilik düzeyi ve bazı mineral madde içerikleri. Doktora tezi, Yüzüncü Yıl Üniversitesi Fen Bilimleri Enstitüsü, Van.

Peinado DMC ve Bedriñana JIC. (2020) Lead and cadmium blood levels and transfer to milk in cattle reared in a mining area. Heliyon, Volume 6, Issue 3, e03579, https://doi.org/10.1016/j.heliyon.2020.e03579.

Qu XY, Zheng N, Zhou XW, Li SL, Wang JQ, Zhang WJ. (2018) Analysis and Risk Assessment of Seven Toxic Element Residues in Raw Bovine Milk in China. Biol Trace Elem Res 183, 92-101 https://doi. org/10.1007/s12011-017-1116-x

Şenol AS ve Özdemir S. (2003) Sakarya bölgesinde kırsal ve kentsel bölgelerden toplanılan sütlerde çinko düzeylerinin belirlenmesi. Sakarya Üniversitesi Fen Bilimleri Enstitüsü Dergisi 7. Cilt 3. Sayı Eylül 2003, 194-196

Tekinşen OC. (2000) Süt ürünleri teknolojisi (3.baskı). Konya: Selçuk Üniversitesi Basımevi, 329 s.

Temiz H ve Soylu A. (2012) Heavy metal concentrations in raw milk collected from different regions of Samsun, Turkey. International Journal of Dairy Technology, 65: 516-522. https://doi.or$\mathrm{g} / 10.1111 / \mathrm{j} .1471-0307.2012 .00846 . x$

Temurci H ve Güner A. (2010) Ankara'da Tüketime Sunulan Süt ve Beyaz Peynirlerde Ağır Metal Kontaminasyonu. Atatürk Üniversitesi Veteriner Bilimleri Dergisi, 1 (2) , 20-28. Retrieved from https:// dergipark.org.tr/tr/pub/ataunivbd/issue/2904/40261

Vıcıl S, Erdoğan S, Uygur V. (2012) Akdağmadeni bölgesi toprak, bitki, koyun kan ve yün örneklerinde bazı esansiyel ve toksik element düzeylerinin saptanması. Adana Veteriner Kontrol Enstitüsü Müdürlüğü Dergisi. 2012,2 (2):15-21 